\title{
STUDIES ON THE EFFECT OF ALUMINUM, ALUMINUM FOIL AND SILICON BAKED CUPS ON ALUMINUM AND SILICON MIGRATION IN CAKES
}

\author{
HAFEZ, H. H. A., ABD EL- SALAM A. M. and HUSEeN, G. H. \\ Technology, Research Institute, ARC, Giza, Egypt.
}

(Manuscript received 9 November 2017)

\begin{abstract}
$\Lambda$ luminum toxicity is well recognized in some diseases, the most effect is observed in Alzheimer's disease. The interaction between food and metal pan can be a potential source of aluminum pollution. Recently, silicon cups are used as healthy and safe cups in baking cakes instead of aluminum cups. In this study, aluminum and silicon levels were determined at three types of cake (orange cake, milk cake and control cake). The cake samples were baked in aluminum cup, aluminum foil cup and silicon cup. The aluminum content increased with prolonged storage time of cake in all types of cups. The level of aluminum was (6.4- $12.17,7.04-14.47$ and $9.02-15.47 \mathrm{mg} / \mathrm{kg}$ ) in cake baked in aluminum foil cup after zero time, 10 and 20 day of storage respectively that followed by the level of aluminum in cake in metallic aluminum cup after zero time, 10 and 20 days of storage (3.4-4.3,3.57-5.6 and $8.06-13.43 \mathrm{mg} / \mathrm{kg}$ ) respectively. On the other hand the silicon level showed little increasing during storage time and ranged from 5-10, $7.3-17.67$ and $8.33-19 \mathrm{mg} / \mathrm{kg}$ at zero time, 10 days and 20 days respectively in all samples. The minimum level of silicone was $5 \mathrm{mg} / \mathrm{kg}$ in control cake at zero time. The results clearly indicate that the use of aluminum foil cups for baking contributes significantly to the daily intake of aluminum through the baked cakes. According to the World Health Organization (WHO), the obtained aluminum values considered to be unacceptable. Finally, excessive consumption of aluminum has an extreme health risk effects.
\end{abstract}

\section{INTRODUCTION}

Aluminum is a factor in the development of serious brain disorders like Alzheimer disease as a result of abnormal accumulation of aluminum within neurons that derived from patients suffering from such diseases. Also aluminum associated with the mobilization of bone phosphate and complication in dialysis dementia and some forms of sclerosis (Julia et al., 2012).

Aluminum reduces the growth rate of human brain cells. Growth rate decrease becomes more pronounced at higher aluminum concentration. Aluminum is found to migrate out from the foil in different stimulants; particularly in distilled water as well as acidic and alkaline media. Migration of aluminum is found significantly higher in acidic and aqueous media in comparison to alcoholic and saline media. Higher 
temperature conditions also enhance the rate of migration of aluminum in acidic and aqueous media. Also, aluminum sulfate is widely used in the tap water filtration process. Aluminum intake from water is very small; yet some studies state that the human body can easily absorb aluminum when found in water (Diamond, 2005)

Aluminium is present in foods naturally or from the use of aluminium -containing food additives. The use of aluminium cookware, utensils, and wrappings can increase the amount of aluminium in food; however, the magnitude of this increase is generally not of practical importance. Foods naturally high in aluminium include potatoes, spinach, and tea. Processed dairy products, flour, and infant formula may be high in aluminium if they contain aluminium- based food additives (WHO, 1997).

In general, food-packaging interactions can be divided into these groups,

- Migration: the transfer of packaging components into food

- Sorption: the transfer of food components to the packaging

- Permeation: the transfer of components through the packaging in either direction Sorption can also be called negative migration

Nowadays, it is a common practice to use silicone cup as healthy and safety pans in baking cake instead of aluminum cups. Silicones as one of the most tested biomaterials, silicones are increasingly used in healthcare and medical applications for their biocompatibility and high performance physical properties. Biocompatibility, hypoallergenic, strength and durability, flexibility bacterial resistance, sterilisability, realistic skin feel stability lubricity and phthalate -free Silicone products for healthcare and medical applications. Robberecht et al., (2009).

Silicon is a trace element for humans, and is absorbed from food in the form of orthosilicic acid. Numerous studies have indicated the important role of silicon for animals and humans. It may positively influence skin and bone structure, increase hair and nail strength and reduce the risk of atherosclerosis, however its essentiality has not been established yet (EFSA, 2004 and Pemaco -Photos, 2009).

Silicon has been shown to stimulate collagen type I synthe-sis and bone mineralization (Seaborn and Nielsen, 2002).

Typical dietary intake of silicon is $20-50 \mathrm{mg} /$ day (EFSA, 2004).

There are no recommendations for daily silicon allowance. However Robberecht et al., (2009) proposed a minimum daily silicon level in the diet within the range of 10-25 $\mathrm{mg} /$ day, based on studies on intake and absorption in humans.

The aim of this research is to detect migration levels of aluminum from metallic aluminum cups and aluminum foil cups in order to evaluate the intake of aluminum in different cake samples during storage in pans to avoid excessive consumption of aluminum. In addition to practice utilizing silicone cup instead of aluminum cups. 


\section{MATERIALS AND METHODS}

\section{Materials:}

-Metallic aluminum cups are made of aluminum oxide is dissolved in a molten salt (cryolite-Na3, AlF6) at temperature 900-1000 C

-Aluminum foil cup is made up of aluminum alloy which is made up of $92-99 \%$ aluminum. It has a thin layer of aluminum oxide to protect it from corrosion.

- Silicone cup flexible, eco-friendly, easy-release, non stick cup. Silicon cup is PVC and phthalate free, and is made from the highest performance, $100 \%$ pure food -grade silicone meeting US, FDA and European food safety standards.

-All types of cup cake (metallic aluminum, aluminum foil and silicone) were purchased from local market in Giza.

-Wheat flour $72 \%$ extraction was obtained from the South Cairo Mill, Company, Egypt.

-Corn oil, eggs, skimmed dry milk, baking powder, salt, sugar, orange fruit and vanilla were purchased from local market in Giza, Egypt.

\section{Methods:}

-Preparation of cup cake:

Cup cakes were prepared according to the method described by (Doweidar, 2001). As follows:

$100 \mathrm{gm}$ wheat flour, $2.3 \mathrm{gm}$ salt, $60 \mathrm{gm}$ sugar, $20 \mathrm{gm}$ corn oil, $4.5 \mathrm{gm}$ baking powder, $10 \mathrm{gm}$ skimmed dry milk, $25 \mathrm{gm}$ fresh whole eggs, $1 \mathrm{gm}$ vanilla, water as required in control cake but orange juice and milk were used instead of water in others samples. Samples were divided to 3 parts, first part without milk or orange juice (control), second part with milk and third part with orange juice.

All dry ingredients were mixed and transferred to mixing machine, eggs were beaten by a whip and vanilla was added to the beaten eggs, corn oil was added to egg-vanilla mixture gradually with well beaten at low speed for 5 min., sugar was added with well beaten at low speed for $5 \mathrm{~min}$. and dry ingredients was added to the mixture gradually and the mixture mixed at low speed for 5 min., scrape down then at medium speed for 2 min., fifty grams of cake dough were scaled into greased cup cake (aluminum cup, aluminum foil cup and silicon cup The cake was baked for 25 min. at $180^{\circ} \mathrm{C}$ the cup cake was allowed to cool $30 \mathrm{~min}$. in the cup and stored in the same baked cup for 10 days and 20 days.

-All cup cake were dried at $50^{\circ} \mathrm{C}$ in air oven, then milled for analysis. 


\section{Chemical analysis}

Moisture, fat, ash, crude fiber crude protein ( $\mathrm{N} \times 5.7)$ and $\mathrm{pH}$

were determined according to AOAC (2005).

-Total carbohydrate was calculated by difference, 100-(protein + fat + ash).

\section{-Determination of aluminum:}

Aluminum was determined according to the method of

Smeyers-Verbeke and Verbeelen (1985) as follow:

Apparatus:

An atomic absorption spectrophotometer (Perkin-Elmer Zeeman 3030) was used with a hydride generator (Perkin -Elmer MHS-10) and an 11-Ma Hallow cathode Lamp, at a slit width of $2.0 \mathrm{~m}$.

Reagents:

All solutions were prepared with ultra pure water obtained by

filtering double -distilled water immediately before use. The standerd solution of aluminum (Merck analytical grade) was used at a concentration of $100 \mathrm{ng} / \mathrm{ml} \mathrm{HNO} 3$ (65\%) HCL (37\%) and HCLO4 (65\%)

Procedure:

Amounts of $300 \mathrm{mg}$ of dried and homogenized samples were treated with $5.0 \mathrm{ml}$ concentrated $\mathrm{HNO} 3$ and heated at $80 \mathrm{C}$ for $1 \mathrm{hr}$. another $5.0 \mathrm{ml}$ mixture of HNO3 and HCLO4 mixture $(4: 1 \mathrm{v} / \mathrm{v})$ were added and heating continued an additional $3 \mathrm{hr}$. until, the sample was completely mineralized After cooling the solution was diluted to a $15 \mathrm{ml} \mathrm{a}(1.9 \% \mathrm{v} / \mathrm{v}) \mathrm{HCL}$ solution. An aliquot of the produced solution was used for the determination of aluminum.

\section{-Determination of silicon}

Silicon was determined as insoluble ash in HCL according to AOAC (2005).

\section{Statistical analysis}

Means of data obtained for samples were analyzed using

Duncan's multiple range test to identify significant differences at the 0.05 probability $(p<0.05)$ using the Statistical Analysis System (SAS, 1999).

\section{RESULTS AND DISCUSSION}

\section{Chemical composition of cake samples}

Concerning chemical composition of baked cake the results in

Table (1) showed that, the highest value of protein (9.11\%).Fat (11.01\%) and ash $(3.11 \%)$ was found in milk cake. fat content was similar in control and orange cakes $(10.6 \%)$. The highest value of fiber and carbohydrates was found in control cake (0.63 and $77.98 \%)$ respectively. 
Table 1. chemical composition (\%) of produced cake (on dry basis).

\begin{tabular}{|l|l|l|l|l|l|}
\hline Sample & Protein & Fat & Ash & Fiber & Carbohydrates \\
\hline Control cake & $8.51^{\mathrm{b}} \pm 0.01$ & $10.60^{\mathrm{a}} \pm 0.10$ & $2.91^{\mathrm{b}} \pm 0.01$ & $0.63^{\mathrm{a}} \pm 0.00$ & $77.98^{\mathrm{a}} \pm 0.01$ \\
\hline Milk cake & $9.11^{\mathrm{a}} \pm 0.10$ & $11.01^{\mathrm{b}} \pm 0.01$ & $3.11^{\mathrm{a}} \pm 0.10$ & $0.62^{\mathrm{a}} \pm 0.00$ & $76.77^{\mathrm{b}} \pm 0.01$ \\
\hline Orange cake & $8.50^{\mathrm{b}} \pm 0.10$ & $10.60^{\mathrm{b}} \pm 0.10$ & $2.99^{\mathrm{b}} \pm 0.10$ & $0.61^{\mathrm{a}} \pm 0.00$ & $77.91^{\mathrm{a}} \pm 0.10$ \\
\hline
\end{tabular}

Values followed by the same letters within the same column were not significantly differences

* Means of triplicate \pm SD.

\section{Aluminum content of cake samples:}

Regarding aluminum content of cake samples the data In Table (2) indicated that aluminum content in control cake, milk cake and orange cake increased during storage especially in orange cake which gave the highest content of aluminum during storage, these results due to that orange juice used in the processing of orange cake. These results agreed with (Onianwa et al., 1997) who reported that the total acidity of orange juice causes the transportation of aluminum from the processing tools and storage cans to the content of the cans. For example, the aluminum content of orange cake baked in aluminum cup was 4.3, 5.6 and $13.43 \mathrm{mg} / \mathrm{kg}$ zero time, 10 days, 20 days respectively.

Moreover, the minimum aluminum content was $3.4,4.98$ and $10.01 \mathrm{mg} / \mathrm{kg}$ in milk cake at zero time, 10 days and 20 days respectively. The data showed the aluminum content in cake (control cake, milk cake and orange cake which baked in aluminum foil cup (the commercial type of cups). The aluminum level ranged from 6.40 to 15.47 $\mathrm{mg} / \mathrm{kg}$ during the experiment. The highest level of aluminum was found in orange cake and was increased by extension of the storage time. We can find that, the aluminum content in cake samples baked in aluminum cups in Table (2) were lower compared to that cake samples which baked in aluminum foil cups. i.e. aluminum content at zero time ranged from 3.40 to $4.30 \mathrm{mg} / \mathrm{kg}$ when cake samples baked in aluminum cup, but the same treatments with cake ranged from 6.40 to $9.02 \mathrm{mg} / \mathrm{kg}$ when cake samples baked in aluminum foil cups. The aluminum was increased by extension of the storage time, it may be due to increase of cake acidity as shown in Table (3).

Adult dietary intakes of aluminium ( $\mathrm{mg} /$ day) have been reported in several countries: Australia (1.9-2.4), Finland (6.7), Germany (8-11), Japan (4.5), Netherlands (3.1), Sweden (13), Switzerland (4.4), United Kingdom (3.9), and USA (7.1-8.2). Intake of children 5-8 years old was $0.8 \mathrm{mg} /$ day in Germany and 6.5 $\mathrm{mg} /$ day in the USA. Infant intakes of aluminium in Canada, the United Kingdom, and the USA ranged from 0.03 to $0.7 \mathrm{mg} /$ day (WHO, 1997). According to generally 
accepted standards, aluminium concentration of cake, muffin such products as a rule should be below $10 \mathrm{mg} / \mathrm{kg}$. This can be readily achieves since migration is technically avoidable by Teflon coating or the use of baking paper (Stahl et al., 2011).

The concentration of aluminum increased up to $21.59-26.71 \mathrm{mg} / \mathrm{kg}$ body weight may be unsafe for consumption for children of lower age as per WHO recommended tolerable limit (1mg/kg bodyweight/day) (FAO/WHO, 1989)

Oral intake of foodstuffs would appear to be the most important source of aluminium. Consequently, the joint FAO/WHO Expert Committee on Food Additives reduced the provisional tolerable weekly intake value for aluminium from $7 \mathrm{mg} / \mathrm{kg}$ body weight/week to $1 \mathrm{mg} / \mathrm{kg}$ body weight/week in order to evaluate the nutritional intake of aluminum. Aluminum cookware, apart from other sources of dietary aluminum, is considered to be a potential source of this metal to human beings.

It could be recommended that there are certain materials that are widely used in bakeries and bake ware that are not fully safe to use. Therefore we advise to use equipments are less reactive with our type of foods, silicone cup showed health impact according to current data as compered by using a particular baking container such as aluminum foil. So that do not recommended for baking or storage of food particularly acidic ones. Finally, health impact of food contaminated with this metal is Alzheimer's disease or in general neurons and kidney faller.

Table 2. Aluminum content in cake baked in metallic aluminum cup and aluminum foil cup ( $\mathrm{mg} / \mathrm{kg}$ ) on dry weight basis.*

\begin{tabular}{|c|c|c|c|c|c|c|}
\hline \multirow{2}{*}{ Sample } & \multicolumn{3}{|c|}{ Metallic aluminum pan } & \multicolumn{3}{|c|}{ Aluminum foil pan } \\
\hline & Zero time & 10 days & 20 days & Zero time & 10 days & 20 days \\
\hline Control cake & $3.40 \pm 0.0 .10^{b}$ & $3.75 \pm 0.10^{c}$ & $8.06 \pm 0.0 .02^{c}$ & $6.40 \pm 0.03^{c}$ & $7.04 \pm 0.03^{c}$ & $9.02 \pm 0.3^{c}$ \\
\hline milk cake & $3.40 \pm 0.10^{b}$ & $4.98 \pm 0.01^{b}$ & $10.01 \pm 0.0 .02^{b}$ & $9.07 \pm 0.09^{b}$ & $11.30 \pm 0.04^{b}$ & $12.02 \pm 0.1^{b}$ \\
\hline orange cake & $4.30 \pm 0.30^{\mathrm{a}}$ & $5.60 \pm 0.20^{\mathrm{a}}$ & $13.43 \pm 0.45^{\mathrm{a}}$ & $12.17 \pm 0.02^{\mathrm{a}}$ & $14.47 \pm 0.2^{\mathrm{a}}$ & $15.47 \pm 0.45^{\mathrm{a}}$ \\
\hline
\end{tabular}

Values followed by the same letters within the same column were not significantly differences

$*$ Means of triplicate \pm SD.

Moisture content and $\mathrm{pH}$ value of cake baked in aluminum cup. Respect moisture content and $\mathrm{pH}$ value of cake baked in aluminum cup at zero time and during storage period are presented in Table (3) the results showed that The moisture content decreased during storage in all samples as a result of cake staling. Moreover, the $\mathrm{pH}$ value in orange cake (6.28) was lower than that in control (9.01) and milk cake (7.84) at zero time these results agreed with Hussein et al., (2011). Jagannatha and Murthy (1990) and Lopez et al., (2002) who found that low pH and temperature enhance the migrating of aluminum from low quality utensils e.g. Al-Pb alloy compare with the high quality utensils e.g. Al-Mn alloy that made from other materials. 
Table 3. Moisture content and $\mathrm{pH}$ value of cake baked in metallic aluminum and aluminum foil cup during storage*

\begin{tabular}{|c|c|c|c|c|c|c|}
\hline \multirow{2}{*}{ Sample } & \multicolumn{2}{|l|}{ Zero time } & \multicolumn{2}{|l|}{10 days } & \multicolumn{2}{|l|}{20 days } \\
\hline & $\mathrm{pH}$ & Moisture & $\mathrm{pH}$ & Moisture & $\mathrm{pH}$ & Moisture \\
\hline Controlcake & $9.01 \pm 0.04^{a}$ & $14.61 \pm 0.1^{\mathrm{a}}$ & $8.99 \pm 0.21^{a}$ & $10.22 \pm 0.51^{b}$ & $8.05 \pm 0.04^{\mathrm{a}}$ & $6.41 \pm 0.59^{c}$ \\
\hline milk cake & $7.84 \pm 0.16^{b}$ & $15.33 \pm 0.68^{\mathrm{a}}$ & $7.2 \pm 0.3^{b}$ & $13.44 \pm 0.56^{\mathrm{a}}$ & $7.04 \pm 0.04^{b}$ & $10.91 \pm 0.09^{a}$ \\
\hline orange cake & $6.28 \pm 0,52^{c}$ & $14.01 \pm 0.99^{\mathrm{a}}$ & $5.47 \pm 0.28^{c}$ & $10.91 \pm 0.09^{b}$ & $6.07 \pm 0.02^{\mathrm{c}}$ & $8.55 \pm 0.45^{b}$ \\
\hline
\end{tabular}

Values followed by the same letters within the same column were not significantly differences

* Means of triplicate \pm SD.

Silicon content of cake samples In relation to the Silicon content of cake samples the obtained data in Table (4) revealed that the maximum content of silicon in orange cake $(10 \mathrm{mg} / 100 \mathrm{gm})$ at zero time and it almost had little increasing by prolonged storage, then milk cake $(10 \mathrm{mg} / 100 \mathrm{gm})$ then control cake $(5 \mathrm{mg} / 100 \mathrm{gm})$ because of the content of silicon in raw materials, these values were almost stable by increasing the storage. However Robberecht et al., (2009) proposed a minimum daily silicon level in the diet within the range of $10-25 \mathrm{mg} /$ day, based on studies on intake and absorption in humans. While, typical dietary intake of silicon is $20-50 \mathrm{mg} /$ day (EFSA, 2004).

Table 4. Silicon level in cake samples $(\mathrm{mg} / 100 \mathrm{gm})$.

\begin{tabular}{|l|l|l|l|}
\hline \multirow{2}{*}{ Sample } & \multicolumn{2}{|l|}{ Silicon $\mathrm{mg} / 100 \mathrm{gm}$} & 20 days \\
\cline { 2 - 4 } & Zero time & 10 days & $8.33 \pm 1.15^{\mathrm{c}}$ \\
\hline Control cake & $5.00 \pm 1.00^{\mathrm{b}}$ & $7.30 \pm 0.57^{\mathrm{c}}$ & $14.00 \pm 0.00^{\mathrm{b}}$ \\
\hline Milk cake & $10.00 \pm 1.00^{\mathrm{a}}$ & $12.67 \pm 1.50^{\mathrm{b}}$ & $19.00 \pm 1.00^{\mathrm{a}}$ \\
\hline Orange cake & $10.00 \pm 4.41^{\mathrm{a}}$ & $17.67 \pm 1.50^{\mathrm{a}}$ & \\
\hline
\end{tabular}

Values followed by the same letters within the same column were not significantly differences

* Means of triplicate \pm SD.

\section{Moisture content and pH value in cake baked in silicon cup}

Moisture content and $\mathrm{pH}$ value of cake baked in silicone cup during storage. As concerns moisture content and $\mathrm{pH}$ value of cake baked in silicone cup during storage the data in Table (5) declared that the $\mathrm{pH}$ and moisture content of cake samples at zero time and during storage period. The moisture content decreased during storage in all samples. Furthermore, the $\mathrm{pH}$ value was the highest value in control one (7.29) at zero time and it decreased with prolonged storage, then milk cake was (7.13) at zero time. The lowest value of $\mathrm{PH}$ was found in orange cake (6.82) at zero time, after 10 days (5.84) and after 20 days (6.12) 
Table 5. Moisture content and pH value of cake baked in silicon cup during storage.*

\begin{tabular}{|l|l|l|l|l|l|l|}
\hline Sample & \multicolumn{2}{|l|}{ Zero time } & \multicolumn{2}{|c|}{10 days } & 20 days \\
\hline & Moisture\% & PH & Moisture $\%$ & PH & Moisture\% & PH \\
\hline Control cake & $14.70 \pm 0.30^{\text {ab }}$ & $7.29 \pm 0.21^{\mathrm{a}}$ & $10.34 \pm 0.66^{\mathrm{b}}$ & $7.98 \pm 0.27^{\mathrm{a}}$ & $6.51 \pm 0.49^{\mathrm{b}}$ & $8.95 \pm 0.2^{\mathrm{a}}$ \\
\hline Milk cake & $15.11 \pm 0.29^{\mathrm{a}}$ & $7.13 \pm 0.27^{\mathrm{ab}}$ & $13.34 \pm 0.7^{\mathrm{a}}$ & $8.12 \pm 0.13^{\mathrm{a}}$ & $10.30 \pm 0.7^{\mathrm{a}}$ & $7.65 \pm 0.25^{\mathrm{b}}$ \\
\hline Orange cake & $13.87 \pm 0.31^{\mathrm{b}}$ & $6.82 \pm 0.08^{\mathrm{b}}$ & $9.51 \pm 0.5^{\mathrm{b}}$ & $5.84 \pm 0.04^{\mathrm{b}}$ & $6.01 \pm 0.99^{\mathrm{b}}$ & $6.12 \pm 0.28^{\mathrm{c}}$ \\
\hline
\end{tabular}

Values followed by the same letters within the same column were not significantly differences

Values are mean \pm standard deviation.

\section{CONCLUSION}

1- Aluminum migration from aluminum foil to the cake is considered to be one of the reasons to accumulate the metal inside the human body especially from aluminum foil cup that may become areasonable agent to Alzheimer's disease or any other unknown serious diseases. Aluminum foil may be used in covering food not for baking or heat treatment. On the other hand, silicone cup can be used instead of aluminum cups in cake baking as safe option

2- The study concluded that the cake should removed from aluminum foil after baking directly and not stored in it.

3- FAO/WHO (2011) announced acceptable daily intake from aluminum (0 to $0.6 \mathrm{mg}$ $\mathrm{Al} / \mathrm{kg} / \mathrm{bw} /$ day). And provisional tolerable weekly intake (0 to $7 \mathrm{mg}$ $\mathrm{Al} / \mathrm{kg} / \mathrm{bw} /$ week)

\section{REFERENCES}

1. AOAC. 2005.Official Methods of Analysis. Association of the Official Ana1ytical Chemists. International 18th Edition, Revision 1, Virginia, USA.

2. Diamond, J. 2005. A report on Alzheimer's disease and current research, Toronto Alzheimer Society of Canada.P. 1-17 (http://www.Alzheimer.ca/en/ research/ Alzheimer.program.

3. Doweidar, M.M. 2001. Chemical and physical studies on some natural resources used in improving bakery products. Ph.D. Thesis, Fac. of Agric., Cairo Univ., Egypt.

4. EFSA, 2004. (European Food Safety Authority) Opinion of the Scientific Panel on Dietetic Products, Nutrition and Allergies (NDA) on related to the Tolerable Upper Intake Level of Silicon. EFSA Journal, 60: 1-11.

5. FAO/WHO. 1989. Evaluation of certain food additives and contaminants. Thirty third report of the Joint FAO/WHO Expert Committee on Food Additives. WHO . Technical Report Series, No.776.

6. FAO/WHO. 2011. Expert Committee on Food Additives.

[http://www.who.int/foodsafety/chem/jecfa/about/en/index.html]. 
7. Hussein, E.A.,A.E. El -Beltagy, and A.M. Gaafar. 2011. Production and evaluation of low calorie cake. Am. J.Food Technol., 6 (9): 827-834.

8. Jagannatha,K. S. and R. R.Murthy. 1990. Aluminum leaching from utensils during cooking and storage. Environment and Ecology, 8: 146-148.

9. -Julia R., P. Ana, A. Salvador, and H.Isabel. 2012. Optimization of a sponge cake formulation with inulin as fat replacer: structure, physicochemical, and sensory properties. j. Food Secienc. 77 (2) : C189-C197.

10. Lopez, F. F., C. Cabrera, M. L.Lorenzo, and M.C.Lopez. 2002. Aluminum content of drinking waters, fruit juices and soft drinks: contribution to dietary intake. Science of the Total Environment, 292, 205-213.

11. Onianwa, P. C., G. C.Ikadeh, , and S. E. Nweze. 1997. Aluminum contents of some raw and processed Nigerian foods. Food Chemistry, 58 (4) : 351-353 .

12. Pemaco-Photos, S. 2009. The Silbione Difference Silicones for Healthcare Applications Bluestar Silicones. www.bluestarsilicones.comhea Ithcare@bluestarsilicones.com.

13. Robberecht, H.;K.Van, D.Bosscher, , and R.Van, 2009. Silicon in Foods: Content and Bioavailability. International Journal of Food Properties, 11(3): 638-645.

14. -SAS. 1999. Statistical Analysis System user gudide statistics. SAS system for windows version 8.1 , vol. 1 SAS institute Inc . cary Inc., USA.

15. Seaborn, C. D., and F. H. Nielsen. 2002. Silicon deprivation decreases collagen formation in wounds and bone, and ornithine transaminase enzyme activity in liver. Biological Trace Element Research, 89 (3) : 251-261.

16. -Smeyers-Verbeke, J. and D.Verbeelen. 1985. Determination of aluminum in bone by Atomic absorption spectroscopy. Clin. Chem., 31 (7) : $1172-1174$.

17. -Stahl , T.,H. Taschan, and H. Brunn. 2011. Aluminium content of selected foods and food products Environmental Sciences Europe: 23-37.

18. -WHO (1997). World Health Organization, International Programme on Chemical Safety (IPCS) (Environmental Health Criteria 194) . Aluminium. Geneva.

19. -Yokel, R. A. 2012. Aluminum in Food -The Nature and Contribution of Food Additives, Food Additive, P.203-228htt://dx.doi.org/10.5772/30847. 


\section{دراسات على تأثير قوالب الخبيزالألومنيوم وورق الألومنيوم و السليكون على هجرة الألومنيوم و السليكون فى الكيك}

هدى حسن ابو السعود حافظ -اميرة محمد عبد الخالق عبد السلام - غادة حسين حامد

$$
\text { معهد بحوث تكنولوجيا الاغذية- مركز البحوث الزراعية- الجيزة-مصر }
$$

يعتبر التسمم بعنصر الألمونيوم من أهم العو امل لحدوث بعض الامراض ومعظم نأثيره يكون

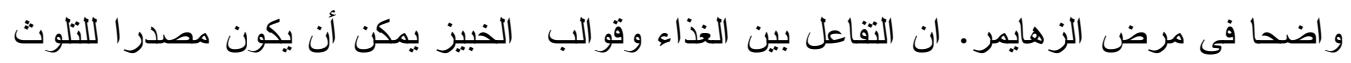

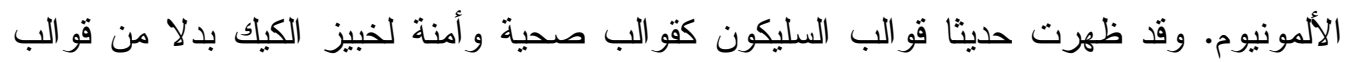

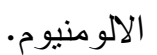

وفى هذه الدراسة تم تقدير مستويات الالومنيوم و السليكون فى ثنلاث أنو اع من الكيك ( كيك الكنترول

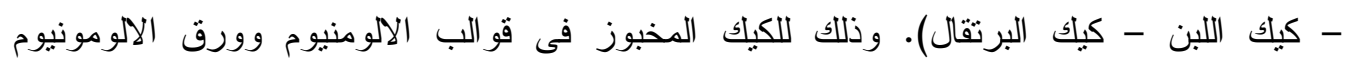
و السليكون مع فترات تخزين مختلفة للكيك فى قو الب الخبيز . وكان أعلى قيم للألومنيوم في في كيك وليك

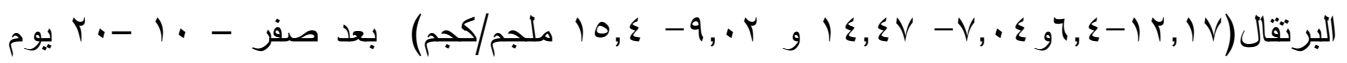

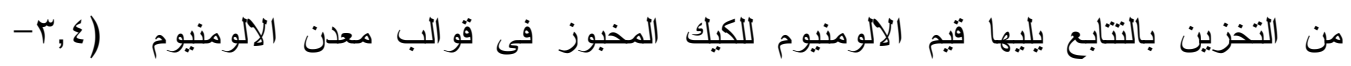

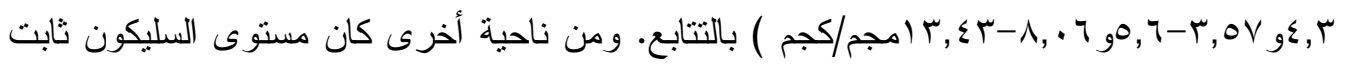

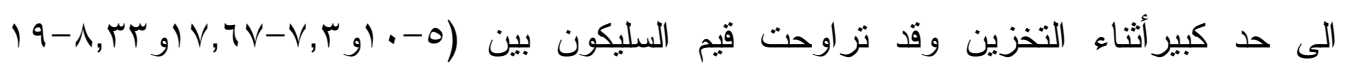

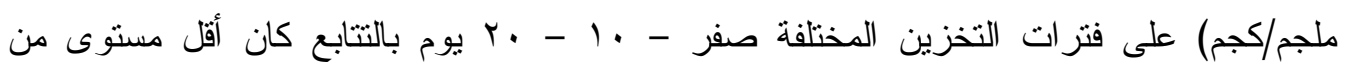
السليكون ( 0 ) ملجم / كجم فى كيك الكنترول فى صفر من التخزين. وأوضحت النتائج أن استخدام قو الب ورق الالومنيوم للخبيز تسهم بقدر معنوى فى زيادة المأخوذ

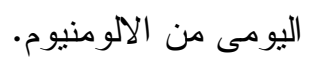
وطبقا لمنظمة الصحة العالمية فان الاستهلاك العالى من الالومنيوم نتيجة استخدام قو الب من ورق

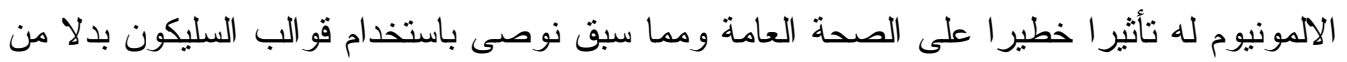
قوالب الالومنيوم وورق الالومنيوم بخاصة فى الخبيز وأن يقتصر استخدام ورق الالومنيوم كمادة 